Article

\title{
Revisiting the Hydrogen Storage Behavior of the Na-O-H System
}

\author{
Jianfeng Mao ${ }^{1}$, Qinfen Gu ${ }^{2}$ and Duncan H. Gregory ${ }^{1, *}$ \\ 1 WestCHEM, School of Chemistry, Joseph Black Building, University of Glasgow, \\ Glasgow G12 8QQ, UK; E-Mail: jeff.mao@hotmail.com \\ 2 Australian Synchrotron, Clayton, Victoria 3168, Australia; E-Mail: Qinfen.Gu@synchrotron.org.au \\ * Author to whom correspondence should be addressed; E-Mail: Duncan.Gregory@Glasgow.ac.uk; \\ Tel.: +44-141-330-6438; Fax: +44-141-330-4888.
}

Academic Editor: Umit Demirci

Received: 19 February 2015 / Accepted: 22 April 2015 / Published: 28 April 2015

\begin{abstract}
Solid-state reactions between sodium hydride and sodium hydroxide are unusual among hydride-hydroxide systems since hydrogen can be stored reversibly. In order to understand the relationship between hydrogen uptake/release properties and phase/structure evolution, the dehydrogenation and hydrogenation behavior of the $\mathrm{Na}-\mathrm{O}-\mathrm{H}$ system has been investigated in detail both ex- and in-situ. Simultaneous thermogravimetric-differential thermal analysis coupled to mass spectrometry (TG-DTA-MS) experiments of $\mathrm{NaH}-\mathrm{NaOH}$ composites reveal two principal features: Firstly, an $\mathrm{H}_{2}$ desorption event occurring between 240 and $380{ }^{\circ} \mathrm{C}$ and secondly an additional endothermic process at around $170{ }^{\circ} \mathrm{C}$ with no associated weight change. In-situ high-resolution synchrotron powder X-ray diffraction showed that $\mathrm{NaOH}$ appears to form a solid solution with $\mathrm{NaH}$ yielding a new cubic complex hydride phase below $200{ }^{\circ} \mathrm{C}$. The $\mathrm{Na}-\mathrm{H}-\mathrm{OH}$ phase persists up to the maximum temperature of the in-situ diffraction experiment shortly before dehydrogenation occurs. The present work suggests that not only is the inter-phase synergic interaction of protic hydrogen (in $\mathrm{NaOH}$ ) and hydridic hydrogen (in $\mathrm{NaH}$ ) important in the dehydrogenation mechanism, but that also an intra-phase $\mathrm{H}^{\delta+} \ldots \mathrm{H}^{\delta-}$ interaction may be a crucial step in the desorption process.
\end{abstract}

Keywords: hydrogen storage; sodium oxide; sodium hydride; sodium hydroxide; in-situ synchrotron powder diffraction 


\section{Introduction}

With the continued depletion of fossil fuel resources and the increasing impact of environmental pollution, renewable and clean energy sources such as wind and solar technologies have become a major priority and been the subject of increased research interest. However, many renewable energy sources are intermittent and so a means by which energy can be stored and transported is vital [1]. One approach is to store energy chemically as a clean fuel and hydrogen is regarded as one of the best options due to its abundance, high gravimetric energy density and capacity to be sustainably generated. However, a means to store hydrogen safely at high capacity and low cost is key to its successful implementation $[2,3]$.

Compared to storage of hydrogen as a compressed gas or a cryogenic liquid, solid-state hydrogen storage is more effective volumetrically and alleviates safety and cost concerns associated with high pressure and/or low temperature. For more than 10 years materials such as light metal hydrides [4], complex hydrides [5-7] and chemical hydrides [8] have been investigated in this capacity and significant advances in understanding and performance have been made. However, no single hydride system yet fulfills all the necessary criteria for mobile applications (principally gravimetric and volumetric capacity, sorption enthalpy and kinetics) [9]. When compared to mobile applications, the requirements for stationary applications are rather different and cycle life/longevity, cost and safety can become the most important parameters [10]. Given the technical demands for portable storage, static medium-large scale hydrogen storage may be at the forefront of initial efforts in energy storage and in shifting electrical energy from peak to off-peak periods to achieve smart grid management. For this purpose, an abundant, low cost and non-toxic hydrogen storage material becomes increasingly attractive to ensure large-scale and long-term applications with the minimum of financial burden.

Among various hydrogen storage materials, sodium based materials are very promising as hydrogen storage media for stationary applications since sodium is one of the most abundant elements on Earth (2.64 $\mathrm{wt} \%$ ), and is relatively cheap [11-15]. Moreover, sodium resources are geographically ubiquitous (e.g. from the sea and from underground deposits). Recently, $\mathrm{Xu}$ et al. found that sodium oxide, $\mathrm{Na}_{2} \mathrm{O}$ can absorb hydrogen easily at close to ambient temperature $\left(\sim 60{ }^{\circ} \mathrm{C}\right)$ to form $\mathrm{NaH}$ and $\mathrm{NaOH}$. Further, the hydrogenated products, $\mathrm{NaH}$ and $\mathrm{NaOH}$, can be readily converted back to $\mathrm{Na}_{2} \mathrm{O}$ by thermal treatment $[16,17]$ :

$$
\mathrm{Na}_{2} \mathrm{O}+\mathrm{H}_{2} \leftrightarrow \mathrm{NaH}+\mathrm{NaOH} \quad \Delta \mathrm{H}=55.65 \mathrm{~kJ} / \mathrm{mol} \mathrm{H} \mathrm{H}_{2}(3.2 \mathrm{wt} \%)
$$

Dehydrogenation in the $\mathrm{NaH}-\mathrm{NaOH}$ system occurs at a lower temperature than that for $\mathrm{NaH}$ alone and given that $\mathrm{NaOH}$ and $\mathrm{NaH}$ contain $\mathrm{H}^{\delta+}$ and $\mathrm{H}^{\delta-}$, respectively, the interaction of these two hydrogen species could be responsible for the relative decrease in dehydrogenation temperature between $\mathrm{Na}-\mathrm{O}-\mathrm{H}$ and $\mathrm{Na}-\mathrm{H}$ [16,17]. The dehydrogenation process and mechanism are still not clear, however. Interestingly a number of much earlier studies of the $\mathrm{Na}-\mathrm{O}-\mathrm{H}$ system have indicated that the alkali metal hydride and corresponding hydroxide may be miscible [18-22]. More recently, during a study of the effect of $\mathrm{NaOH}$ as an additive in the $\mathrm{Na}-\mathrm{H}$ system, it was observed that $c a .10 \mathrm{~mol} \% \mathrm{of} \mathrm{NaOH}$ could apparently be incorporated into the $\mathrm{NaH}$ structure and resulted in enhanced hydrogen motion in $\mathrm{NaH}$ above $150{ }^{\circ} \mathrm{C}$ [23]. These previous results suggest that $\mathrm{OH}^{-}$can be substituted for $\mathrm{H}^{-}$within the $\mathrm{NaH}$ structure above $150{ }^{\circ} \mathrm{C}$. Given the connectivity between proton conduction and hydrogen 
uptake/release kinetics [24], an investigation of the structural and phase composition changes in the Na-O-H system during heating should provide considerable insight into the desorption mechanism and ultimately in how the performance of the system might be improved. In this paper, we present a detailed study of hydrogenation and dehydrogenation in the Na-O-H system, particularly exploiting in-situ synchrotron X-ray powder diffraction methods to elucidate the subtle changes in composition and structure immediately prior to hydrogen release.

\section{Results and Discussion}

\subsection{Hydrogenation of $\mathrm{Na}_{2} \mathrm{O}$}

The time-resolved hydrogenation profile of as-milled $\mathrm{Na}_{2} \mathrm{O}$ with temperature (at 18 bar) is shown in Figure 1. On heating at $3{ }^{\circ} \mathrm{C} \mathrm{min}-1$, hydrogen uptake is initiated close to room temperature $\left(30-50{ }^{\circ} \mathrm{C}\right)$. Upon heating to $140{ }^{\circ} \mathrm{C}$, the hydrogen uptake rate increases significantly and $2.5 \mathrm{wt} \% \mathrm{H}_{2}$ can be stored under these conditions. Subsequently, hydrogenation is relatively slow and a total of $3.3 \mathrm{wt} \%$ hydrogen is absorbed by $400{ }^{\circ} \mathrm{C}$. These uptake results are consistent with previous studies [16,17], although it should be noted that the experimental figure of $3.3 \mathrm{wt} \%$ slightly exceeds the theoretical capacity. In principle, this could be possible due to the partial reaction of $\mathrm{Na}_{2} \mathrm{O}$ with moisture during hydrogen uptake, but powder X-ray diffraction (PXD) patterns before and after hydrogenation suggest that the reaction of an impurity in the starting material with hydrogen may also contribute as discussed below.

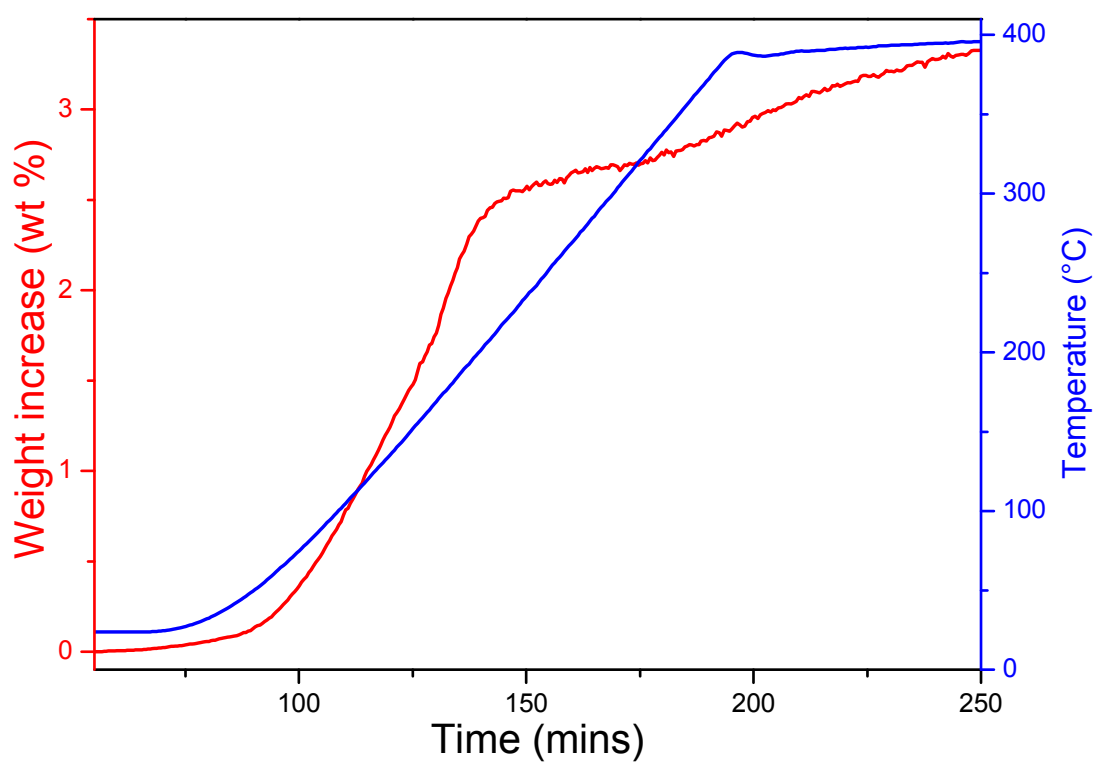

Figure 1. Hydrogen uptake of as-milled $\mathrm{Na}_{2} \mathrm{O}$ under 18 bar of hydrogen.

PXD was performed to clarify the chemical reactions that occur on hydrogenation. Figure 2 shows the PXD patterns of the $\mathrm{Na}_{2} \mathrm{O}$ starting material after mechanical milling (sample 1), the material after hydrogenation (sample 2) and finally after subsequent dehydrogenation (sample 3). Although $\mathrm{Na}_{2} \mathrm{O}$ was the main phase in the ball milled starting material as expected, an impurity phase of $\mathrm{Na}_{2} \mathrm{O}_{2}$ was also detected, and analysis of the diffraction pattern yielded a phase fraction of $c a$. $10 \mathrm{wt} \%$. After hydrogenation at $400{ }^{\circ} \mathrm{C}, \mathrm{NaH}$ and $\mathrm{NaOH}$ were formed and the diffraction peaks from $\mathrm{Na}_{2} \mathrm{O}$ and $\mathrm{Na}_{2} \mathrm{O}_{2}$ were no longer present. Upon dehydrogenation at $400{ }^{\circ} \mathrm{C}, \mathrm{Na} 2 \mathrm{O}$ reformed and was present as 
the majority phase. Overall, therefore, the material system demonstrated a reversible reaction as described by Equation 1. The presence of $\mathrm{NaOH}$ in the dehydrogenated product, sample 3 could suggest partial hydrolysis of $\mathrm{Na}_{2} \mathrm{O}$, but the more likely origin of the hydroxide is from hydrogenation of the original $\mathrm{Na}_{2} \mathrm{O}_{2}$ impurity in the starting material (since $\mathrm{Na}_{2} \mathrm{O}_{2}+\mathrm{H}_{2} \rightarrow 2 \mathrm{NaOH}$ ). This leads to an excess of $\mathrm{NaOH}$ in the hydrogenated product, sample 2 (i.e., $\mathrm{NaH}: \mathrm{NaOH}$ is not in the expected 1:1 molar ratio following hydrogen uptake) which persists during the dehydrogenation process at $400{ }^{\circ} \mathrm{C}$ However, Rietveld refinement for hydrogenated $\mathrm{Na}_{2} \mathrm{O}$ shows that the molar ratio of $\mathrm{NaOH}$ and $\mathrm{NaH}$ in the sample is $1.66: 1$. The phase fraction of $\mathrm{NaOH}$ exceeds the amount expected solely from the hydrogenation of $10 \mathrm{wt} \% \mathrm{Na}_{2} \mathrm{O}_{2}$. Thus, both the hydrolysis of $\mathrm{Na}_{2} \mathrm{O}$ (and possibly of $\mathrm{NaH}$ ) and the hydrogenation of the original $\mathrm{Na}_{2} \mathrm{O}_{2}$ impurity lead to the observed excess of $\mathrm{NaOH}$.

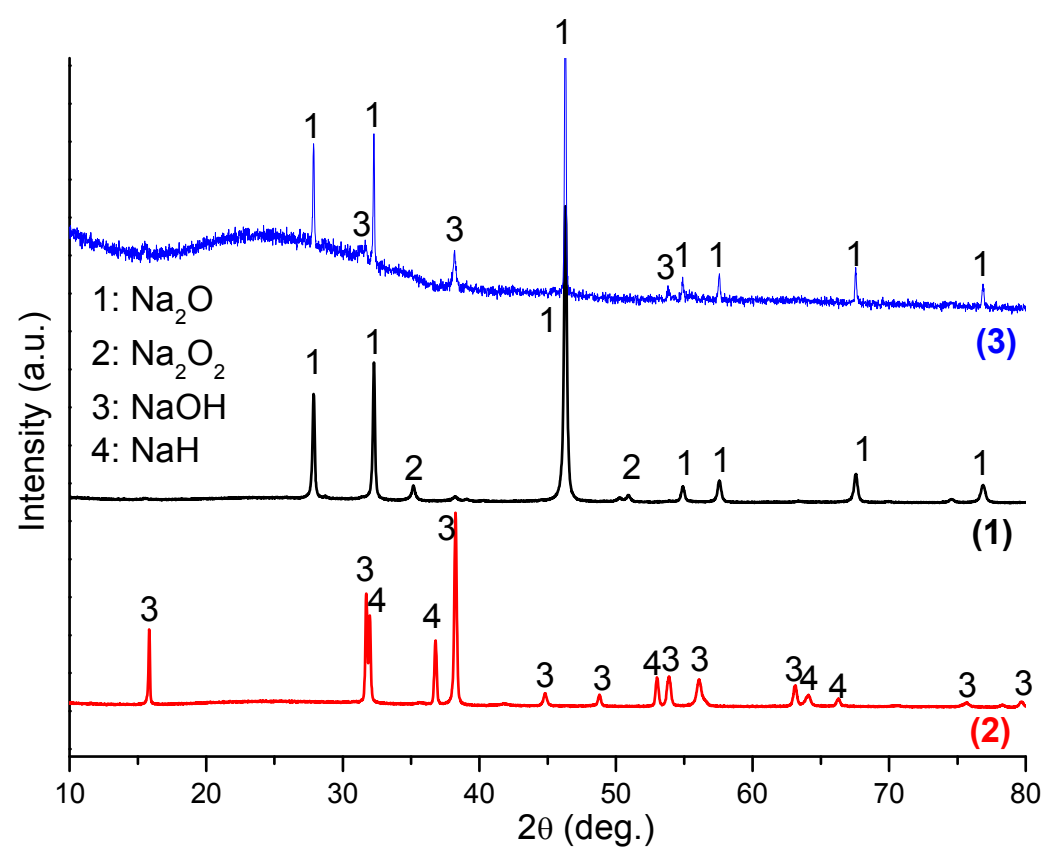

Figure 2. XRD patterns of $\mathrm{Na}_{2} \mathrm{O}$ after ball milling (sample 1), after hydrogenation at $400{ }^{\circ} \mathrm{C} / 18$ bar $\mathrm{H}_{2}$ (sample 2), and after subsequent dehydrogenation at $400{ }^{\circ} \mathrm{C}$ (sample 3 ).

\subsection{Dehydrogenation of $\mathrm{NaH}-\mathrm{NaOH}$}

The dehydrogenation process in the $\mathrm{NaH}-\mathrm{NaOH}$ system was investigated further. Figure 3 shows a PXD pattern of the as-milled mixture of $\mathrm{NaH}-\mathrm{NaOH}$ (molar ratio 1:1; sample 4) as compared with the individual commercial starting materials $\mathrm{NaH}$ and $\alpha-\mathrm{NaOH}$. It can be seen that the as-received $\mathrm{NaH}$ contains a small amount of $\mathrm{NaOH}$ impurity, while the as-received $\mathrm{NaOH}$ contains a minor phase of the hydrated hydroxide, $\mathrm{NaOH} \cdot \mathrm{H}_{2} \mathrm{O}$. By comparison, only $\mathrm{NaH}$ and $\mathrm{NaOH}$ were detected in sample 4 . The absence of the $\mathrm{NaOH} \cdot \mathrm{H}_{2} \mathrm{O}$ impurity in sample 4 is attributed to dehydration during ball milling. 


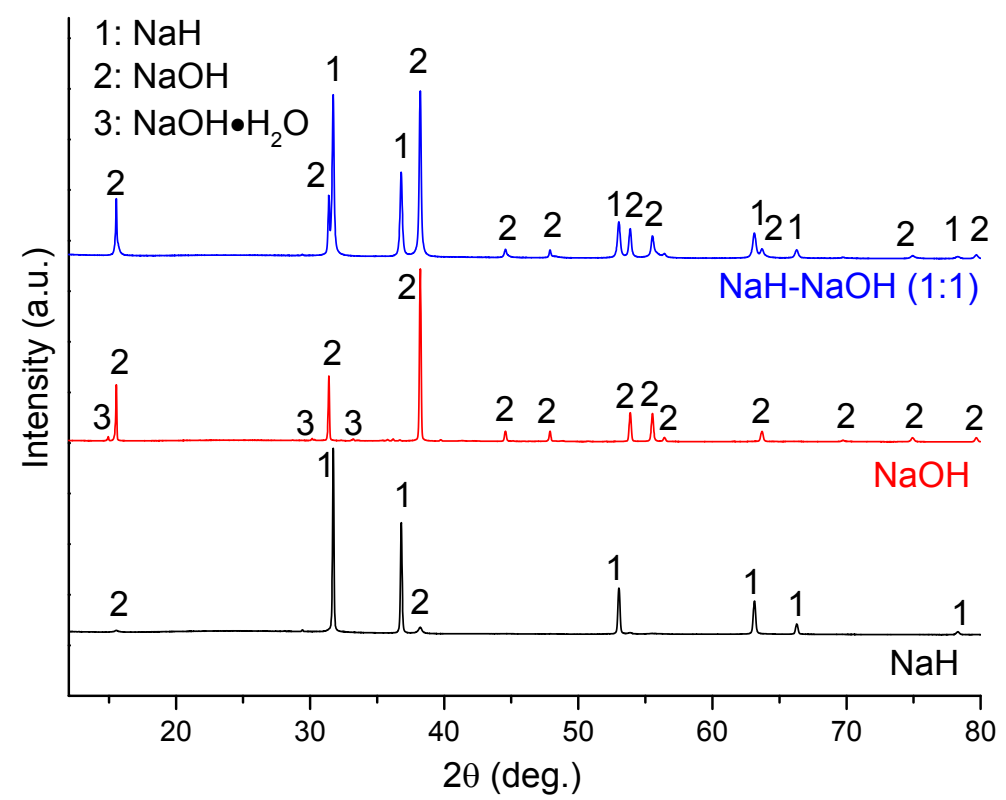

Figure 3. PXD patterns of as-received $\mathrm{NaH}$ and $\mathrm{NaOH}$, and as-milled $\mathrm{NaH}-\mathrm{NaOH}$ (1:1), sample 4.

The thermal decomposition behavior of sample 4 compared to $\mathrm{NaH}$ and $\mathrm{NaOH}$ was investigated by DTA, as shown in Figure 4. The DTA profile for $\mathrm{NaH}$ shows one endothermic peak at $c a .360{ }^{\circ} \mathrm{C}$, which can be assigned to the decomposition of $\mathrm{NaH}$ to $\mathrm{Na}$ metal and hydrogen. For $\mathrm{NaOH}$, the DTA profile shows two endothermic peaks at 299 and $319{ }^{\circ} \mathrm{C}$, which can be assigned to the $\alpha-\beta$ (orthorhombic-monoclinic) phase transition and the melting point, respectively $[25,26]$. By contrast, sample 4 shows different features, displaying multiple endothermic peaks. The first endothermic event occurs at $171{ }^{\circ} \mathrm{C}$ and is relatively well-defined while the second is more complex (consisting of perhaps three or more individual processes) and reaches a maximum in the DTA profile at $333{ }^{\circ} \mathrm{C}$. The second endothermic event can be attributed to the reaction of $\mathrm{NaH}$ and $\mathrm{NaOH}$ culminating in the formation of $\mathrm{Na}_{2} \mathrm{O}$ and hydrogen. The results further confirmed that the dehydrogenation pathway of the $\mathrm{NaH}-\mathrm{NaOH}$ mixture is entirely different to that observed for $\mathrm{NaH}$. The first endothermic event is not observed in either $\mathrm{NaH}$ or $\mathrm{NaOH}$. It would appear therefore that the synergic interaction of hydrogen species in $\mathrm{NaH}$ and $\mathrm{NaOH}$ not only contributes to the lower dehydrogenation temperature $v s$. $\mathrm{NaH}$ itself, but also leads to likely reaction in the solid state and structural changes during the heating period prior to dehydrogenation. To clarify the structural changes that occur before dehydrogenation, variable temperature, in-situ synchrotron PXD experiments were conducted on the NaH-NaOH mixture and are discussed below.

Ex-situ XRD characterization was performed on several dehydrogenated hydride-hydroxide mixtures of varying molar ratio after heating each to $400{ }^{\circ} \mathrm{C}$ (Figure 5). Clearly, $\mathrm{Na}_{2} \mathrm{O}$ was the main phase in the dehydrogenated $\mathrm{NaH}-\mathrm{NaOH}(1: 1)$ sample, but some residual $\mathrm{NaOH}$ remains also detected. In this case, the presence of residual $\mathrm{NaOH}$ can be attributed to the fact that the $\mathrm{NaH}$ and $\mathrm{NaOH}$ starting materials contain low levels of $\mathrm{NaOH}$ and $\mathrm{NaOH} \cdot \mathrm{H}_{2} \mathrm{O}$ impurities, respectively. Hence the $\mathrm{NaH}: \mathrm{NaOH}$ ratio departs from the ideal stoichiometric 1:1 value in the mixture. In order to obtain single phase $\mathrm{Na}_{2} \mathrm{O}$ as a dehydrogenation product, we optimized the quantity of $\mathrm{NaH}$ and $\mathrm{NaOH}$ in the starting mixture. As shown in Figure 5, $\mathrm{NaOH}$ impurity reflections diminished as the $\mathrm{NaH}: \mathrm{NaOH}$ ratio increased, reaching a minimum when a $23 \mathrm{wt} \%$ excess of $\mathrm{NaH}$ was used. On adding a $25 \mathrm{wt} \%$ excess 
of $\mathrm{NaH}$, no $\mathrm{NaOH}$ was observed in diffraction patterns but reflections originating from $\mathrm{Na}$ metal appeared. Therefore, use of $23 \mathrm{wt} \%$ excess of $\mathrm{NaH}$ was found to be the optimum reactant composition required to obtain $\mathrm{Na}_{2} \mathrm{O}$ with minimal impurities (sample 5).

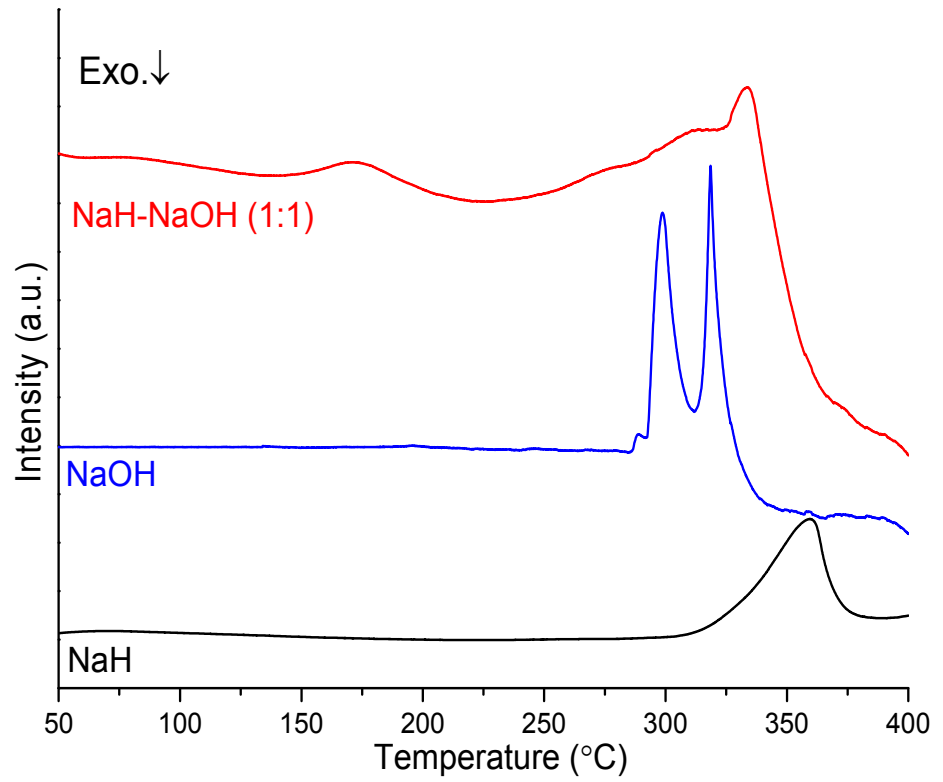

Figure 4. DTA profiles of $\mathrm{NaH}, \mathrm{NaOH}$, and as-milled $\mathrm{NaH}-\mathrm{NaOH}(1: 1)$ mixture.

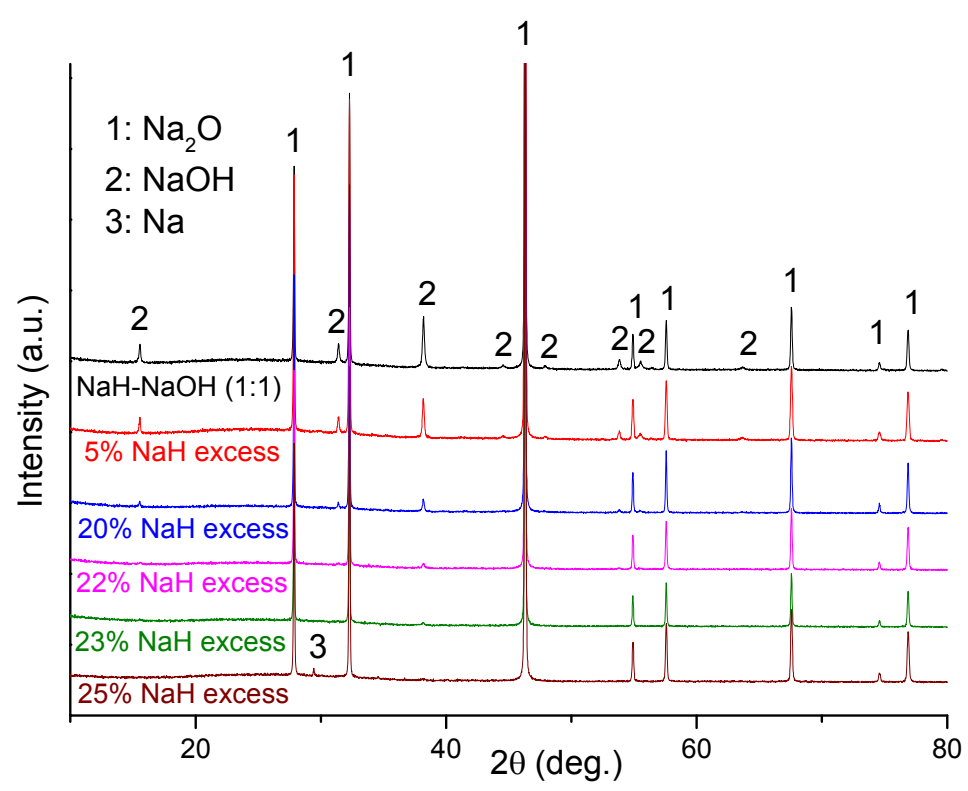

Figure 5. PXD patterns of $\mathrm{NaH}-\mathrm{NaOH}$ with varying hydride:hydroxide molar ratio after dehydrogenation at $400{ }^{\circ} \mathrm{C}$.

The thermal behavior of sample 5 was investigated by TG-DTA-MS (Figure 6). TG results showed that the mixture released gas from $200-378{ }^{\circ} \mathrm{C}$ with a corresponding weight loss of $3.1 \mathrm{wt} \%$. Moreover, it was evident from mass spectra collected simultaneously while heating that hydrogen was the only evolved gaseous product, consistent with the reversible reaction described by equation 1 . The DTA profile for sample 5 reveals a similar feature with the sample $\mathrm{NaH}-\mathrm{NaOH}(1: 1)$. The first endothermic peak was observed at $170{ }^{\circ} \mathrm{C}$, while the second cluster of overlapping endothermic peaks with a 
maximum at $342{ }^{\circ} \mathrm{C}$ is attributed to the dehydrogenation reaction of $\mathrm{NaH}$ with $\mathrm{NaOH}$ and might be expected to incorporate first the $\alpha-\beta$ phase transition and second the melting of $\mathrm{NaOH}$.
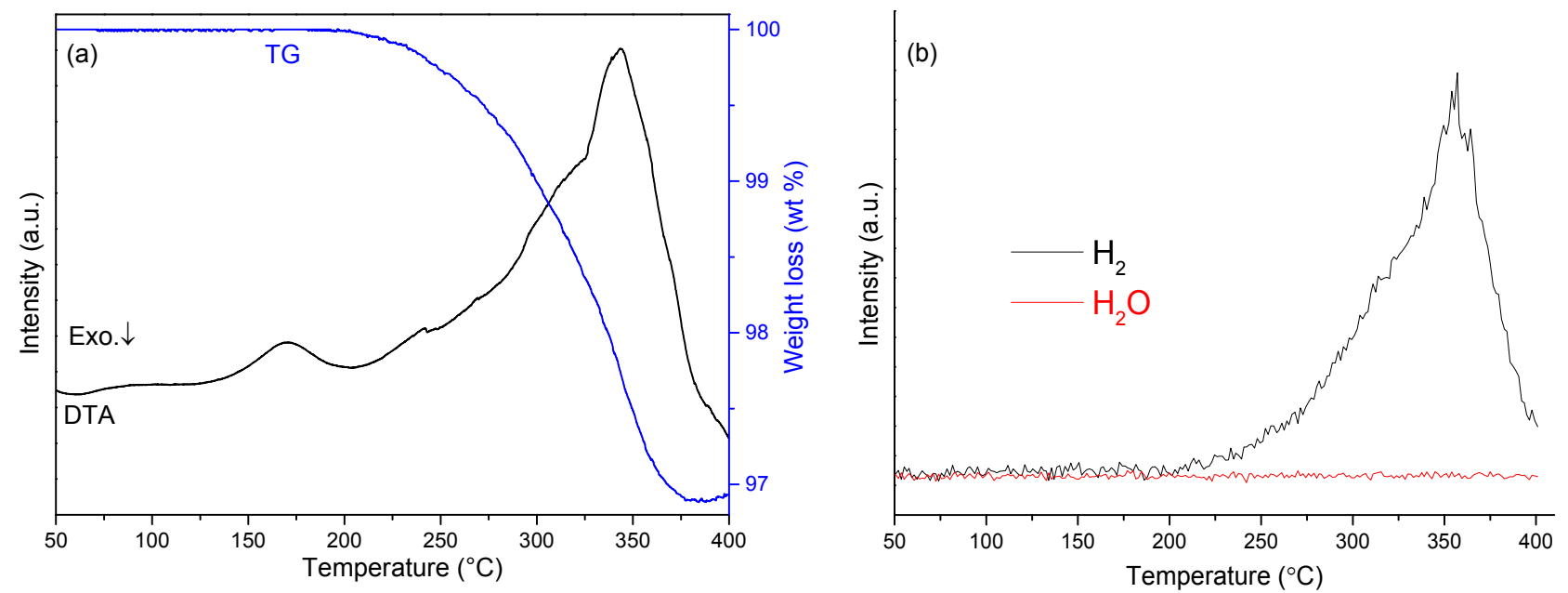

Figure 6. Simultaneous TG-DTA-MS profiles of sample 5: (a) TG-DTA traces; (b) mass spectra for hydrogen and water.

\subsection{In-Situ Synchrotron Powder Diffraction}

In-situ synchrotron PXD methods were used to clarify the reaction mechanism underpinning the first endothermic event at $c a .170{ }^{\circ} \mathrm{C}$ by heating sample 5 from room temperature to $260{ }^{\circ} \mathrm{C}$. Figure 7 shows selected regions of the in-situ diffraction patterns for sample 5, the relevant peak indices and a plot of the resulting cell volume changes of the $\mathrm{NaH}$ and $\mathrm{NaOH}$ phases, respectively, as a function of temperature. Structure refinements performed against the synchrotron PXD data were conducted for each data set (see supplementary information). A fundamental parameter (FP) approach was employed in TOPAS to perform whole-pattern profile fitting of the diffraction data collected in transmission mode. The diffraction background was fitted with Chebychev functions. Structural data from the ICDD PDF4 (2014) database for $\mathrm{NaH}(02-0809)$ and $\alpha-\mathrm{NaOH}(078-0188)$ were used as starting models in TOPAS. At room temperature $\mathrm{NaH}$ crystallizes in cubic space group $F m \overline{3} m$ (No.225; $a=4.8826(1) \AA$ ), while $\alpha-\mathrm{NaOH}$ is orthorhombic (Cmcm, No. 63; $a=3.4039(1) \AA, b=3.4011(1) \AA, c=11.3901(1) \AA$ ).

Before heating, room temperature PXD data show that sample 5 consists only of $\mathrm{NaH}(44 \mathrm{wt} \%)$ and $\mathrm{NaOH}(56 \mathrm{wt} \%)$. There are no impurity diffraction peaks observed in the PXD pattern. As shown in Figure 7, below $110{ }^{\circ} \mathrm{C}$, reflections for both $\mathrm{NaH}$ and $\mathrm{NaOH}$ shift slightly to lower angle with increasing temperature. This shift corresponds to the expected thermal expansion of the $\mathrm{NaH}$ and $\mathrm{NaOH}$ lattices. The cell volume for $\mathrm{NaH}$ increases from $c a .116 .4 \AA^{3}$ to $c a .118 .5 \AA^{3}$ over this temperature range, corresponding to a volume expansion of approximately $1.8 \%$. Over the same temperature range, the cell volume for $\mathrm{NaOH}$ increases by approximately $0.99 \%$ and the phase fractions of $\mathrm{NaH}$ and $\mathrm{NaOH}$ remain effectively constant, indicating that no reaction occurs between the hydride and hydroxide.

From $110^{\circ} \mathrm{C}$, all the $\mathrm{NaH}$ peaks become increasingly asymmetric with some evidence of reflections emerging at slightly higher $2 \theta$ values to the main peaks as manifested by a broadening tail to all $\mathrm{NaH}$ reflections. Meanwhile, the $\mathrm{NaH}$ peaks shift continuously to lower $2 \theta$ angles and the hydride cell 
volume increases significantly such that at $180{ }^{\circ} \mathrm{C}$ the value is approximately $7.2 \%$ larger compared to that at room temperature (Figure 7e). Most significantly, however, starting from $190{ }^{\circ} \mathrm{C}$, the $\mathrm{NaH}$ peaks become asymmetric at lower diffraction angle while simultaneously the $\mathrm{NaOH}$ diffraction peaks become weaker. As can be seen clearly for the $\mathrm{NaH} 200$ reflection at $2 \theta \sim 22.4^{\circ}$ (Figure $7 \mathrm{~b}$ ), as the temperature increases a new peak starts to appear at a slightly lower $2 \theta$ angle. Given that every $\mathrm{NaH}$ peak splits in the same sense and that all the original reflections are also retained, the phenomenon indicates the formation of a slightly larger unit cell with a structure type common to the original $\mathrm{NaH}$ phase. This indicates that a new NaH-like phase with slightly larger lattice parameters is formed as $\mathrm{NaOH}$ becomes depleted.
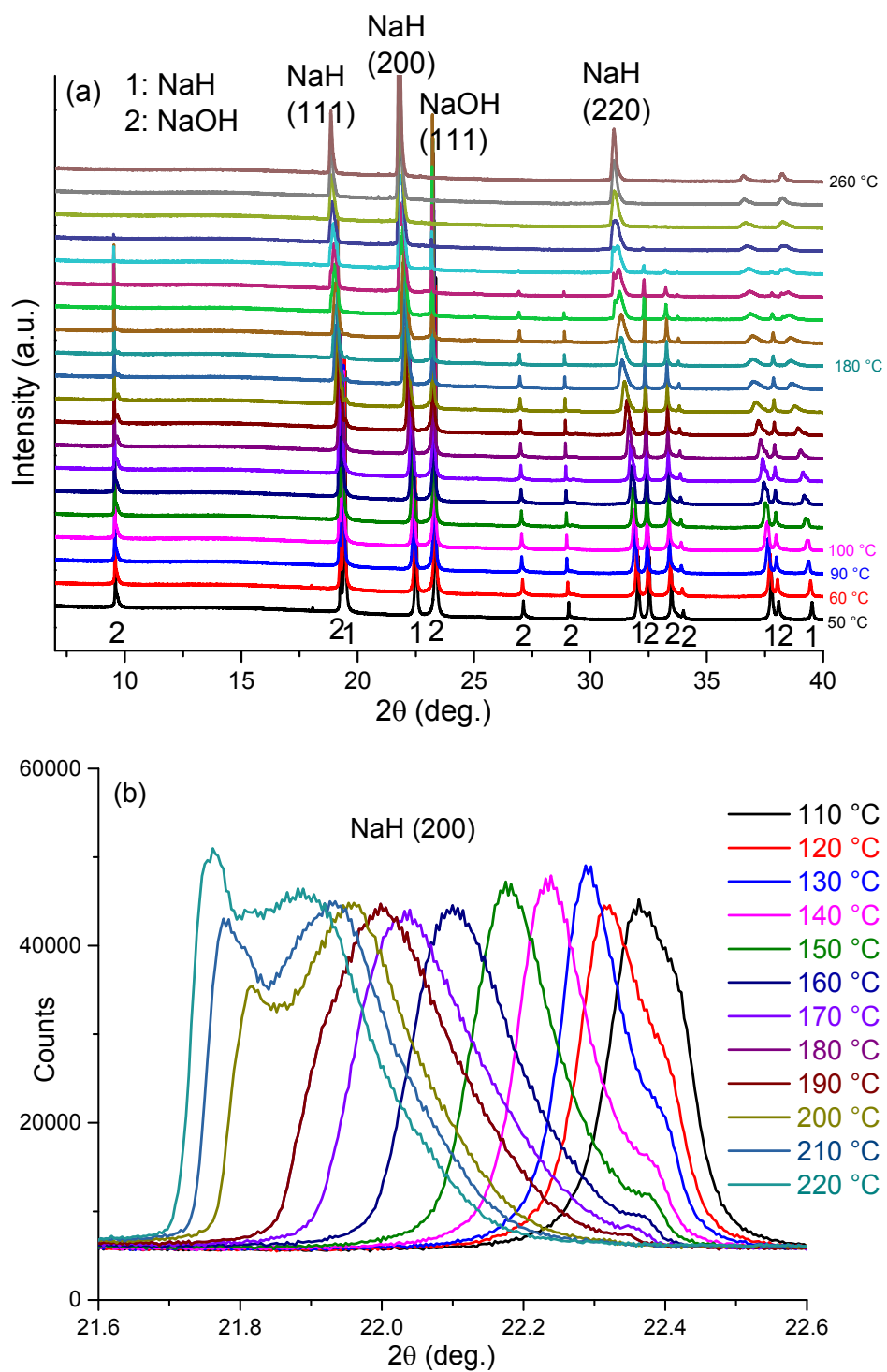

Figure 7. Cont. 

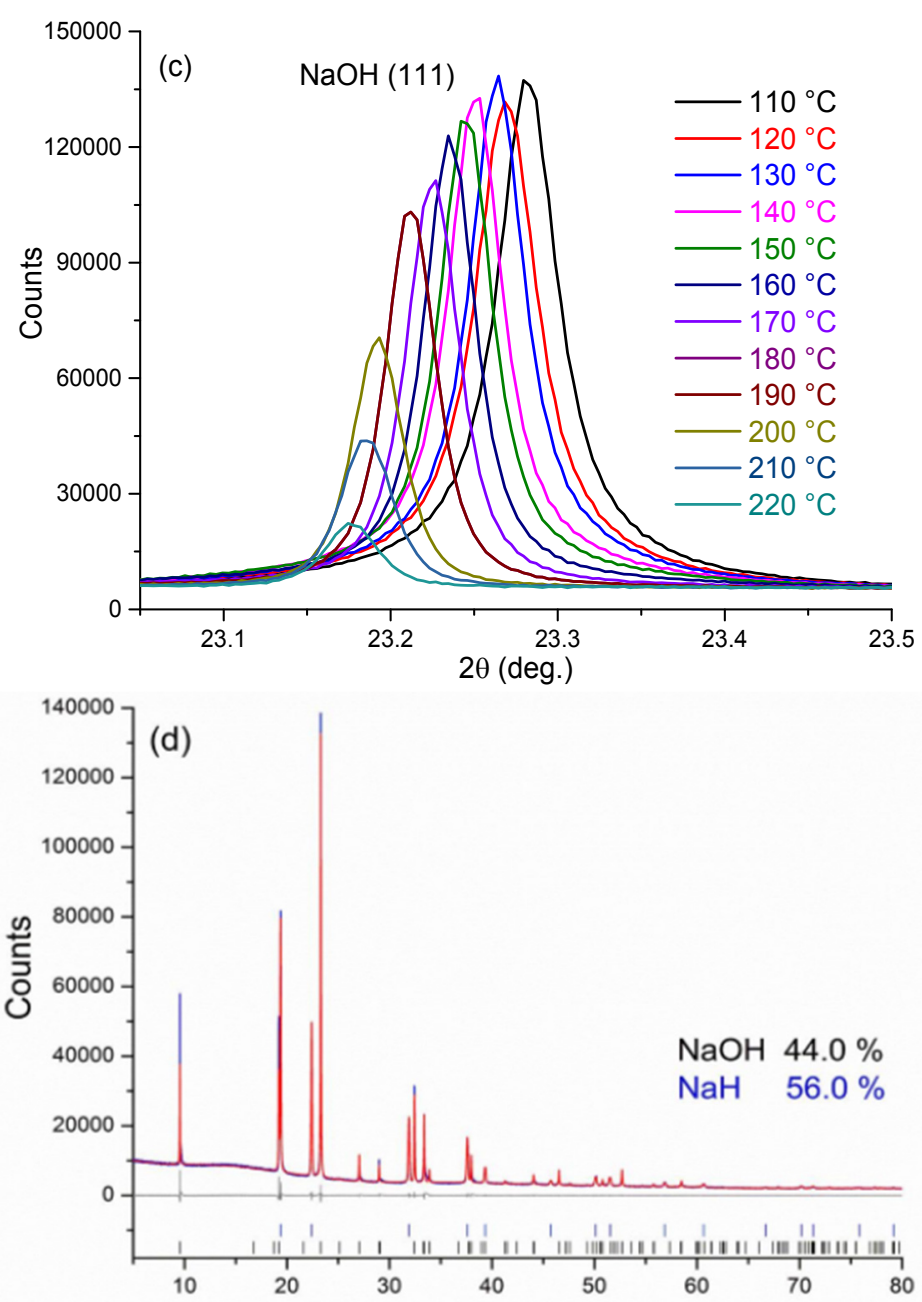

$2 \theta$ (deg.)

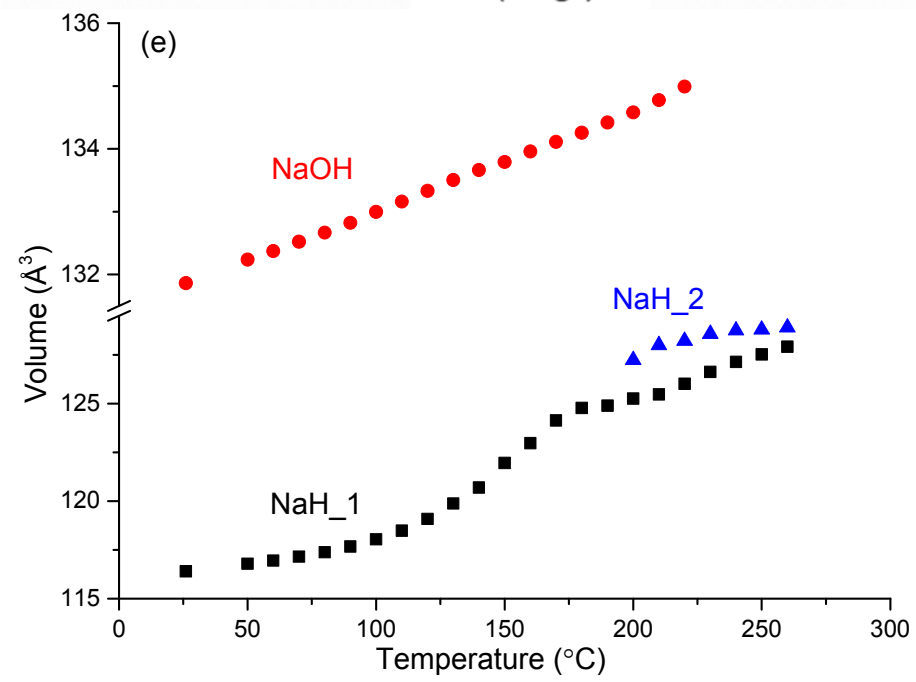

Figure 7. In-situ synchrotron PXD patterns for sample 5 heated from room temperature to $260{ }^{\circ} \mathrm{C}$ with a constant heating rate of $10{ }^{\circ} \mathrm{C} \mathrm{min}^{-1}$ in a closed quartz capillary under $\mathrm{Ar}$ atmosphere ( $\lambda=0.9533 \AA$ ) showing: (a) the region from $7^{\circ} \leq 2 \theta \leq 40^{\circ}$; (b) the change in the $\mathrm{NaH}$ (200) reflections from 110 to $220^{\circ} \mathrm{C}$; (c) the change in the $\mathrm{NaOH}$ (111) reflections from 110 to $220{ }^{\circ} \mathrm{C}$; (d) the refinement profile at $100{ }^{\circ} \mathrm{C}$; and (e) cell volume against temperature for $\mathrm{NaH}$ ("NaH_1"), "Na-O-H" ("NaH_2") and $\mathrm{NaOH}$, respectively, from room temperature to $260^{\circ} \mathrm{C}$. 
By $240{ }^{\circ} \mathrm{C}$ there is no evidence of $\mathrm{NaOH}$ in the diffraction patterns and the $\mathrm{NaH}$-like phase reflections become more symmetric and sharper, indicative of a single phase. Also noteworthy is that there is no evidence for the formation of $\mathrm{Na}_{2} \mathrm{O}$ over the entire temperature range of the experiment. The cell volume of the hydride at $240{ }^{\circ} \mathrm{C}$ is $127.1 \AA^{3}$, which is approximately $9.2 \%$ larger as compared to the room temperature $\mathrm{NaH}$ structure. The results suggest that a structural change begins from $110{ }^{\circ} \mathrm{C}$ and that by $190{ }^{\circ} \mathrm{C} \mathrm{NaOH}$ reacts appreciably with $\mathrm{NaH}$ in the solid state to form a complex hydride with an NaH-type structure. As the temperature increases further, a single composition of the NaH-like phase is formed. Thus we propose that an $\mathrm{NaH}-\mathrm{NaOH}$ solid solution forms in which up to $50 \%$ of the hydride is replaced by hydroxide; $\mathrm{NaH}_{1-\mathrm{x}}(\mathrm{OH})_{\mathrm{x}}$ where $\mathrm{x} \leq 0.5$. Hence, one might reasonably speculate that the formation of the hydride-hydroxide is the vital precursor to an intraphase $\mathrm{H}^{\delta} \ldots \mathrm{H}^{\delta-}$ interaction and the hydrogen evolution step during desorption.

The process could thus be represented by the modified version of the reaction equation below:

$$
\mathrm{NaH}+\mathrm{NaOH} \rightarrow 2 \mathrm{NaH}_{0.5}(\mathrm{OH})_{0.5} \rightarrow \mathrm{Na}_{2} \mathrm{O}+\mathrm{H}_{2}
$$

When compared with other $A \mathrm{H}-A \mathrm{OH}(A \mathrm{OH})_{2}$ systems $(A=\mathrm{Li}, \mathrm{K}, \mathrm{Mg})$, similar solid solution behavior has only been observed previously in the K-O-H system [19]. On heating, however, $\mathrm{KOH}-\mathrm{KH}$ does not apparently combine to form $\mathrm{K}_{2} \mathrm{O}$, but rather $\mathrm{KH}$ decomposes independently while $\mathrm{KOH}$ remains to $500{ }^{\circ} \mathrm{C}$ [17]. By contrast, in the $\mathrm{LiOH}-\mathrm{LiH}$ system, although the final decomposition reaction product is $\mathrm{Li}_{2} \mathrm{O}$, no solid solution phases are reported prior to oxide formation upon heating, which might be a consequence of the relatively low dehydrogenation temperature [17,27,28]. There is no strong evidence for solid solution formation in the $\mathrm{MgH}-\mathrm{Mg}(\mathrm{OH})_{2}$ system prior to dehydrogenation [29]. $\mathrm{Na}-\mathrm{O}-\mathrm{H}$ is unique among these four hydroxide-based combinations as the only system with the appropriate thermodynamics for reversible hydrogen storage. The present work suggests that for hydroxide-hydride materials not only is the inter-phase synergic interaction of protic hydrogen (in $\mathrm{NaOH}$ ) and hydridic hydrogen (in $\mathrm{NaH}$ ) important in the dehydrogenation mechanism, but that also an intra-phase $\mathrm{H}^{\delta+} \ldots \mathrm{H}^{\delta-}$ interaction may be a crucial step in the desorption process. Furthermore, the ensuing lattice expansion and anion disorder of the sodium hydride hydroxide could play a significant role in the diffusion of hydrogen in the solid state either or both as protons and hydride. The mobility of one or both of these species is likely to be key to mediating and controlling the hydrogen uptake and release kinetics in this and similar systems. Strategies involving nanostructuring, additives and catalysts are likely to be crucial in the development of cheap, abundant materials systems such as hydroxides into potentially useful hydrogen stores.

\section{Experimental Section}

$\mathrm{Na}_{2} \mathrm{O}$ (Alfa Aesar, anhydrous, 90\%), $\mathrm{NaH}$ (Sigma Aldrich, dry, 95\%), and $(\alpha-) \mathrm{NaOH}$ (Sigma Aldrich, reagent grade, 97\%) were used as received. Before the hydrogenation or dehydrogenation experiments, $\mathrm{Na} 2 \mathrm{O}$ and $\mathrm{NaH}-\mathrm{NaOH}$ mixtures (employing different $\mathrm{NaH}: \mathrm{NaOH}$ molar ratios as indicated elsewhere in the text), respectively, were milled using a $50 \mathrm{~mL}$ stainless steel milling jar under argon atmosphere in a Retsch PM100 planetary ball mill. Milling was performed at $400 \mathrm{rpm}$ for $1 \mathrm{~min}$ in one direction, paused for $1 \mathrm{~min}$ and then reversed to give a total milling duration of $1 \mathrm{~h}$. 
A ball:powder mass ratio of approximately 50:1 was employed throughout. All manipulations were performed in an Ar-filled recirculating glovebox (Saffron Scientific, 1 ppm $\mathrm{H}_{2} \mathrm{O}, 1$ ppm $\mathrm{O}_{2}$ ).

Room temperature ex-situ powder X-ray diffraction (PXD) experiments were conducted with a Bruker D8 powder diffractometer in transmission geometry with spinning sealed capillaries. Diffraction data for phase identification were typically collected over $5^{\circ} \leq 2 \theta \leq 85^{\circ}$ with a $0.017^{\circ}$ step size and scan times of 1 or $10 \mathrm{~h}$.

Synchrotron PXD data were collected using incident radiation with $\lambda=0.9533 \AA$ using a Mythen-II detector at the powder diffraction beamline, Australian Synchrotron. Time-resolved in situ high temperature measurements were conducted with a flow cell under an atmosphere of 1 bar argon (99.99\%) using a Cyberstar hot air blower to heat the quartz capillary from $50{ }^{\circ} \mathrm{C}$ to $260{ }^{\circ} \mathrm{C}$ at a constant heating rate of $10{ }^{\circ} \mathrm{C} \mathrm{min}$. Data were collected with an exposure time of $150 \mathrm{~s}$ at every $10{ }^{\circ} \mathrm{C}$ step. Data analysis was performed using the TOPAS 4.2 software package [30].

Hydrogen absorption experiments were performed on an intelligent gravimetric analyzer (IGA, Hiden, Warrington, UK) with samples of $\sim 50 \mathrm{mg}$ contained in stainless steel sample holders. Hydrogen gas (BOC, 99.98\%; Motherwell, UK) at 18 bar was introduced into the reaction chamber and absorption was performed between 20 and $400{ }^{\circ} \mathrm{C}$ with a fixed ramp rate of $3{ }^{\circ} \mathrm{C} \min ^{-1}$. The variation in sample mass and temperature with time was recorded.

Thermal behavior of $\mathrm{NaH}-\mathrm{NaOH}$ samples was analyzed via simultaneous thermogravimetric-differential thermal analysis with coupled mass spectrometry (TG-DTA-MS; Netzsch STA 409 coupled to a Hiden Analytical HPR20 mass spectrometer; Selb, Germany) in an Ar-filled recirculating glovebox (MBraun UniLab; Garching, Germany, 1 ppm $\mathrm{H}_{2} \mathrm{O}, 1 \mathrm{ppm} \mathrm{O}$ ). Samples of $c a .20 \mathrm{mg}$ were loaded into alumina pans and heated to $673 \mathrm{~K}$ under a flow of $\mathrm{Ar}$ gas at a rate of $5{ }^{\circ} \mathrm{C} \mathrm{min}^{-1}$ in order to achieve complete decomposition of the samples.

\section{Conclusions}

In summary, the Na-O-H reversible hydrogen storage system has been examined in detail. The (de)hydrogenation behavior of the Na-O-H system was investigated by means of IGA measurements, simultaneous TG-DTA-MS, XRD, and in-situ synchrotron PXD. $\mathrm{Na}_{2} \mathrm{O}$ starts to absorb hydrogen at temperatures slightly above ambient $\left(30-50^{\circ} \mathrm{C}\right)$ under a relatively low hydrogen pressure (18 bar). The hydrogenated products, $\mathrm{NaH}$ and $\mathrm{NaOH}$, release hydrogen at a lower temperature than the binary hydride $\mathrm{NaH}$. Moreover, differential thermal analysis shows an endothermic event near $170{ }^{\circ} \mathrm{C}$ in the $\mathrm{NaH}-\mathrm{NaOH}$ system that cannot be associated with the dehydrogenation reaction of the mixture or with phase transitions of either of the individual components. In-situ synchrotron PXD results show that $\mathrm{NaOH}$ forms a solid solution with $\mathrm{NaH}$ that persists until $240{ }^{\circ} \mathrm{C}$. The $\mathrm{NaH}$ and $\mathrm{Na}(\mathrm{H}, \mathrm{OH})$ cubic phases demonstrate a large volume expansion in the temperature range of $160-240{ }^{\circ} \mathrm{C}$. The resulting predominantly intraphase interaction of protic hydrogen and hydridic hydrogen provides a likely driving force for the subsequent dehydrogenation in the hydride-hydroxide system.

\section{Acknowledgments}

The research post for JM has received funding from the European Union's Seventh Framework 610 Programme (FP7/2007-2013) for the Fuel Cells and Hydrogen Joint Technology Initiative under Grant 
611 Agreement number 303447. Part of the experiment was conducted at the Powder diffraction beamline at the Australian Synchrotron.

\section{Author Contributions}

Jianfeng Mao performed the synthesis, PXD and hydrogen performance characterization; Qinfen Gu performed the synchrotron measurements; Duncan H. Gregory was responsible for planning and supervising the research. All authors discussed the results and co-wrote the manuscript.

\section{Conflicts of Interest}

The authors declare no conflict of interest.

\section{References}

1. Hadjipaschalis, I.; Poullikkas, A.; Efthimiou, V. Overview of current and future energy storage technologies for electric power applications. Renew. Sust. Energy Rev. 2009, 13, 1513-1522.

2. Schlapbach, L.; Züttel, A. Hydrogen-storage materials for mobile applications. Nature 2001, 414, 353-358.

3. Mandal, T.K.; Gregory, D.H. Hydrogen: Future energy vector for sustainable development. Proc. Inst. Mech. Eng. Part C J. Mech. Eng. Sci. 2010, 224, 539-558.

4. Schüth, F.; Bogdanović, B.; Felderhoff, M. Light metal hydrides and complex hydrides for hydrogen storage. Chem. Commun. 2004, 20, 2249-2258.

5. Orimo, S.; Nakamori, Y.; Eliseo, J.; Züttel, A.; Jensen, C.M. Complex hydrides for hydrogen storage. Chem. Rev. 2007, 107, 4111-4132.

6. Mandal, T.K.; Gregory, D.H. Hydrogen storage materials: Present scenarios and future directions. Ann. Rep. Prog. Chem. Sect. A Inorg. Chem. 2009, 105, 21-54.

7. Reardon, H.; Hanlon, J.; Hughes, R.W.; Godula-Jopek, A.; Mandal, T.K.; Gregory, D.H. Emerging concepts in solid-state hydrogen storage: The role of nanomaterials design. Energy Env. Sci. 2012, 5, 5951-5979.

8. Hamilton, C.W.; Baker, R.T.; Staubitzc, A.; Manners, I. B-N compounds for chemical hydrogen storage. Chem. Soc. Rev. 2009, 38, 279-293.

9. Targets for Onboard Hydrogen Storage Systems for Light-Duty Vehicles. Available online: http://energy. gov/sites/prod/files/2014/03/f12/targets_onboard_hydro_storage.pdf (accessed on 23 April 2015).

10. Ibrahim, H.; Ilinca, A.; Perron, J. Energy storage systems-Characteristics and comparisons. Renew. Sust. Energy Rev. 2008, 12, 1221-1250.

11. Mao, J.F.; Gregory, D.H. Recent advances in the use of sodium borohydride as a solid state hydrogen store. Energies 2015, 8, 430-453.

12. Mao, J.F.; Guo, Z.P.; Liu, H.K. Improved hydrogen sorption performance of $\mathrm{NbF}_{5}$-catalysed $\mathrm{NaAlH}_{4}$. Int. J. Hydrogen Energy 2011, 36, 14503-14511.

13. Mao, J.F.; Guo, Z.P.; Nevirkovets, I.P.; Liu, H.K.; Dou, S.X. Hydrogen De-/Absorption improvement of $\mathrm{NaBH}_{4}$ catalyzed by Titanium-based additives. J. Phys. Chem. C 2012, 116, 1596-1604. 
14. Mao, J.F.; Guo, Z.P.; Liu, H.K.; Dou, S.X. Reversible storage of hydrogen in NaF-MB $(\mathrm{M}=\mathrm{Mg}, \mathrm{Al})$ composites. J. Mater. Chem. A 2013, 1, 2806-2811.

15. Mao, J.F.; Yu, X.B.; Guo, Z.P.; Liu, H.K.; Wu, Z.; Ni, J. Enhanced hydrogen storage performances of $\mathrm{NaBH}_{4}-\mathrm{MgH}_{2}$ system. J. Alloys Compd. 2009, 479, 619-623.

16. Xu, Q.; Wang, R.T.; Kiyobayashi, T.; Kuriyama, N.; Kobayashi, T. Reaction of hydrogen with sodium oxide-A reversible hydrogenation/dehydrogenation system. J. Power Sources 2006, 155, 167-171.

17. Yu, P.; Chua, Y.S.; Cao, H.J.; Xiong, Z.T.; Wu, G.T.; Chen, P. Hydrogen storage over alkali metal hydride and alkali metal hydroxide composites. J. Energ. Chem. 2014, 23, 414-419.

18. Gnanasekaran, T. Thermochemistry of binary $\mathrm{Na}-\mathrm{NaH}$ and ternary $\mathrm{Na}-\mathrm{O}-\mathrm{H}$ systems and the kinetics of reaction of hydrogen/water with liquid sodium-A review. J. Nucl. Mater. 1999, 274, 252-272.

19. Mikheeva, V.I.; Shkrabkina, M.M. Solid solutions in the NaOH-NaH and KOH-KH systems. Russ. J. Inorg. Chem. 1962, 7, 1251-1255.

20. Jansson, S.A. Thermochemistry and solution chemistry in the sodium-oxygen-hydrogen system. In Corrosion by Liquid Metals, 2nd ed.; Draley, J.E., Weeks, J.R., Eds.; Springer: New York, NY, USA, 1970; Session V, pp. 523-560.

21. Myles, K.M.; Cafasso, F.A. The reciprocal ternary system Na-NaOH-Na2O-NaH. J. Nucl. Mater. 1977, 67, 249-253.

22. Veleckis, E.; Leibowitz, L. Phase relations for reactions of hydrogen with sodium oxide between 500 and $900^{\circ}$ C. J. Nucl. Mater. 1987, 144, 235-243.

23. Sorte, E.G.; Majzoub, E.H.; Ellis-Caleo, T.; Hammann, B.A.; Wang, G.; Zhao, D.X.; Bowman, R.C., Jr.; Conradi, M.S. Effects of $\mathrm{NaOH}$ in Solid NaH: Solution/Segregation Phase Transition and Diffusion Acceleration. J. Phys. Chem. C 2013, 117, 23575-23581.

24. David, W.I.F.; Jones, M.O.; Gregory, D.H.; Jewell, C.M.; Johnson, S.R.; Walton, A.; Edwards, P.P. A mechanism for non-stoichiometry in the Lithium Amide/Lithium imide hydrogen storage reaction. J. Am. Chem. Soc. 2007, 129, 1594-1601.

25. Bleif, H.-J.; Dachs, H. Crystalline modifications and structural phase transitions of $\mathrm{NaOH}$ and NaOD. Acta. Cryst. A 1982, 38, 470-476.

26. Douglas, T.B.; Dever, J.L. Anhydrous sodium hydroxide: The heat content from 0 to $700{ }^{\circ} \mathrm{C}$, the transition temperature, and the melting point. J. Res. Natl. Bur. Stand. 1954, 53, 81-90.

27. Kiat, J.M.; Boemare, G.; Rieu, B.; Aymes, D. Structural evolution of LiOH: Evidence of a solid-solid transformation toward $\mathrm{Li}_{2} \mathrm{O}$ close to the melting temperature. Solid State Commun. 1998, 108, 241-245.

28. Vajo, J.J.; Skeith, S.L.; Mertens, F.; Jorgensen, S.W. Hydrogen-generating solid-state hydride/hydroxide reactions. J. Alloys Compd. 2005, 390, 55-61.

29. Leardini, F.; Ares, J.R.; Bodega, J.; Fernández, J.F.; Ferrer, I.J.; Sánchez, C. Reaction pathways for hydrogen desorption from magnesium hydride/hydroxide composites: Bulk and interface effects. Phys. Chem. Chem. Phys. 2010, 12, 572-577.

30. User Manual; Bruker AXS: Karlsruhe, Germany, 2005.

(C) 2015 by the authors; licensee MDPI, Basel, Switzerland. This article is an open access article distributed under the terms and conditions of the Creative Commons Attribution license (http://creativecommons.org/licenses/by/4.0/). 